\title{
Comparative analysis of xanafide cytotoxicity in breast cancer cell lines
}

\author{
N Alami' ${ }^{1,3}$, J Paterson'2, S Belanger', S Juste', CK Grieshaber² and B Leyland-Jones*,1 \\ 'Department of Oncology, McGill University, 546 Pine Ave West, Montreal, QC, H2W IS6 Canada; ${ }^{2}$ Xanthus Pharmaceuticals Inc., 300 Technology \\ Square, 5th Floor, Cambridge, MA 02139, USA
}

Xanafide, a DNA-intercalating agent and topoisomerase II inhibitor, has previously demonstrated comparable cytotoxicity to the parent drug amonafide (NSC 308847). The current study was conducted to investigate further the anti-proliferative effects of xanafide in human breast cancer cell lines, in vitro and in vivo. The in vitro activity of xanafide against MCF-7, MDA-MB-23I, SKBR-3 and T47D cell lines was compared to that of paclitaxel, docetaxel, gemcitabine, vinorelbine and doxorubicin. In MCF-7, xanafide demonstrated comparable total growth inhibition (TGI) concentrations to the taxanes and lower TGI values than gemcitabine, vinorelbine and doxorubicin. MCF-7 (oestrogen receptor (ER) +/p53 wild-type) was the most sensitive cell line to xanafide. MDAMB-23I and SKBR-3 exhibited similar sensitivity to xanafide. T47 D (ER +/p53 mutated), showed no response to this agent. The in vivo activity of xanafide was further compared to that of docetaxel in MCF-7 and MDA-MB-23I cell lines using the hollow fibre assay. Xanafide was slightly more potent than docetaxel, at its highest dose in MCF-7 cell line, whereas docetaxel was more effective than xanafide in MDA-MB-23 I cell line. Our results show that there is no relationship between sensitivity of these cell lines to xanafide and cellular levels of both isoforms of topoisomerase $\|$ and suggest that ER and p53 status and their crosstalk may predict the responsiveness or resistance of breast cancer patients to xanafide.

British Journal of Cancer (2007) 97, 58-64. doi: I0.1038/sj.bjc.6603829 www.bjcancer.com

Published online 5 June 2007

(c) 2007 Cancer Research UK

Keywords: breast cancer; xanafide; topoisomerase II; oestrogen receptor; p53

Breast cancer is the most common malignancy affecting women in the Western world. Systemic chemotherapy is indicated for women with metastatic breast cancer (MBC) that is oestrogen/ progesterone-negative or unresponsive to hormonal therapy, or rapidly progressing and life-threatening (Hortobagyi and Piccart-Gebhart, 1996). Several single-agent chemotherapeutic options have been shown to be effective as first- or second-line therapy in the management of $\mathrm{MBC}$ with the taxanes and anthracyclines being among the most active drugs (Pronzato and Rondini, 2006).

The taxanes, paclitaxel and docetaxel, bind to, and stabilise microtubules, causing cell-cycle arrest and apoptosis (Schiff et al, 1979). The overall response rates achieved in MBC patients were 29-63 and 47-65\%, with paclitaxel and docetaxel, respectively (Montero et al, 2005). However, side effects such as hypersensitivity reactions, myelosuppression and neuropathy were observed with the taxanes, although docetaxel causes less neuropathy and more myelotoxicity (Ghersi et al, 2005).

Anthracyclines are active agents in primary adjuvant and palliative treatment of breast cancer (Kroger et al, 1999). Doxorubicin intercalates among DNA base pairs resulting in conformational

* Correspondence: Dr B Leyland-Jones;

E-mail: brian.leyland-jones@mcgill.ca

${ }^{3}$ Current address: VM Institute of Research, 6100 Royalmount Av, Montreal QC H4P 2R2, Canada.

Received 7 August 2006; revised 3 May 2007; accepted 3 May 2007; published online 5 June 2007 changes in DNA structure and changes in the activity of topoisomerase. In $\mathrm{MBC}$, response rates to single doxorubicin treatment range from $52 \%$ in previously untreated patients to $28 \%$ in patients previously exposed to an alkylating agent (Esteva et al, 2001). In patients who failed to respond to anthracycline and taxanes treatment, administration of capecitabine, gemcitabine or vinorelbine has been shown to result in overall response rates of $20-25 \%$ (Livingston et al, 1997; Blum et al, 1999; Valerio et al, 2001). Gemcitabine, an antimetabolite pyrimidine analogue, and vinorelbine, which inhibits microtubule polymerisation, have been widely investigated in the treatment of MBC (Martin et al, 2007).

In view of previous studies, in clinical practice, the potential therapeutic impact of standard chemo-agents for breast cancer is often limited due to intrinsic and/or acquired drug resistance in addition to drug-related toxicity. Therefore, balancing efficacy and toxicity is a major challenge, and the optimal choice of chemotherapy must be driven by patient and disease characteristics such as menopausal status, oestrogen and progesterone receptor status, Her-2 neu expression (Gralow, 2005), and tumour characteristics such as p53 gene involved in tumour response to therapy (Vogelstein et al, 2000).

Given the current status of the breast cancer treatment and to further improve the clinical outcome in these patients, new treatment approaches are needed.

Naphthalimides are DNA-intercalating agents that bind to DNA by insertion between the base pairs of the double helix. Intercalation causes the base pairs to separate vertically, thereby distorting the sugar-phosphate backbone and changing the degree 
of rotation between successive base pairs. Naphthalimides were designed by combining structural components of several antitumour compounds into a small molecule and have shown high antitumour activity upon a variety of murine and human tumour cells (Brana and Ramos, 2001). One of these compounds, amonafide (Sami et al, 1993) has been verified to exert ATPindependent topo II-mediated DNA cleavage (Andersson et al, 1987; Hsiang et al, 1989; Dorr et al, 2001). Furthermore, this agent is not affected by the multidrug resistance phenomenon and is not an efflux pump substrate (Dorr et al, 2001).

In previous clinical studies, amonafide demonstrated activity for the treatment of MBC (Costanza et al, 1995). However, it is metabolised to an active but myelosuppressive metabolite, the $\mathrm{N}$-acetyl amonafide. A population study in women with breast cancer established that wide variation in the major side-effect of neutropenia was related to inter-individual patient differences in $\mathrm{N}$-acetylating activity. Importantly, at the same prescribed dose, slow NAT2 acetylators were believed to be underdosed as reflected by minimal response rate and lack of grade 3 myelosuppression while rapid acetylators had greater haematologic toxicity attributed to slower clearance of the parent amonafide (Ratain et al, 1991, 1993). These data, and that from other studies in a variety of major tumour types, led to the conclusion that amonafide should not be considered for further clinical development.

Xanafide (amonafide L-malate), a novel salt formulation of amonafide, has been developed. Preliminary pharmacological and chemical equivalence studies demonstrated that xanafide had comparable pharmacokinetics and toxicity in vitro and in vivo, while having superior solubility, stability and compressibility than the parent drug, amonafide (personal communication). Individualising the dose of xanafide as a function of NAT2 phenotype may optimise patient safety and therapeutic benefit. Xanafide has recently received the FDA Orphan Drug Designation for the treatment of acute myeloid leukaemia (AML) and has now entered phase II clinical trials in patients with secondary AML.

The present study is the first one to report preclinical evaluation of xanafide. Our aim was to compare xanafide activity to standard breast cancer agents (paclitaxel, docetaxel, vinorelbine, gemcitabine and doxorubicin) in a panel of four breast cancer cell lines: MCF-7, MDA-MB-231, SKBR-3 and T47D, in vitro, and against paclitaxel in the first two cell lines, in vivo. This panel included oestrogen receptor (ER)-positive and ER-negative cell lines, since it has been shown that oestrogen can enhance the effects of topoisomerase II inhibitors in ER-responsive breast cell lines (Epstein and Smith, 1988).

\section{MATERIALS AND METHODS}

\section{Cell lines}

MCF-7, MDA-MB-231, SKBR-3 and T47D were obtained from the American Type Culture Collection (ATCC) (Rockville, MD, USA). Cell lines were grown in RPMI-1640 medium (Invitrogen, Gaithersburg, MD, USA), supplemented with $10 \%$ fetal bovine serum, $2 \mathrm{~mm}$ L-glutamine at $37^{\circ} \mathrm{C}$ in a humidified atmosphere containing $5 \% \mathrm{CO}_{2}$.

\section{Chemicals and compounds}

All general chemicals were purchased from Sigma Chemical Co. (St Louis, MO, USA) unless otherwise specified. Xanafide was kindly provided by Xanthus Life Sciences. Paclitaxel, docetaxel, doxorubicin, vinorelbine and gemcitabine are commercially available. Before in vitro use, a $1 \mathrm{~mm}$ stock solution of each agent was prepared by dilution in culture media. Polyvinylidene fluoride hollow fibres (500000 Da molecular weight cutoff, $1.0 \mathrm{~mm} \mathrm{ID)} \mathrm{were} \mathrm{purchased}$ from Spectrum Medical Industries (Luguan Hills, CA, USA).
Animals

Athymic NCr $n u / n u$ mice, 5-6 weeks of age were purchased from Taconic (Germantown, NY, USA). All studies involving these animals were conducted in accordance with National Cancer Institute (NCI) protocol and the McGill University Animal Care and Ethics guidelines.

\section{Cytotoxicity assay}

Cytotoxicity studies were performed using the sulphorhodamine B assay (Skehan et al, 1990). Cytotoxicity of each drug was evaluated by the $\mathrm{GI}_{50}$ and TGI values, representing the $50 \%$ growth inhibition and total growth inhibition, respectively, compared to non-treated control (C) and a control at time of addition of increasing drug concentrations (Tz). On day 1, MCF-7 \& SKBR-3 (5000 cells) and MDA-MB-231 \& T47D (20000 cells) were seeded into 96-well plates in a volume of $100 \mu \mathrm{l}$ per well. On day 2, one plate of each cell line was fixed in situ with trichloroacetic acid (TCA) to establish the cell population at time of drug addition (Tz). An aliquot of $100 \mu \mathrm{l}$ of serial dilutions of the different agents was added to the appropriate well, resulting in a series of final concentrations ranging from $0.1 \mathrm{nM}$ to $100 \mu \mathrm{M}$. After $48 \mathrm{~h}$ of drug exposure, the medium in control and drug-containing wells was removed. Cells were washed with cold phosphate-buffered saline (PBS) and then precipitated with $50 \mu$ lice-cold 50\% TCA and fixed for $60 \mathrm{~min}$ at $4^{\circ}$. The supernatant was discarded, and cells were washed five times with tap water and air-dried. Fixed cells were then dyed with $50 \mu \mathrm{l}$ of $0.4 \%$ sulphorhodamine B in $1 \%$ acetic acid solution and the plates were incubated for $10 \mathrm{~min}$ at room temperature. Unbound dye was removed by washing with $1 \%$ acetic acid and the plates were air-dried. Sulphorhodamine B was dissolved in $150 \mu \mathrm{l}$ of $10 \mathrm{~mm}$ Tris-buffer ( $\mathrm{pH} 10.5$ ) and $540 \mathrm{~nm}$ optical density was measured in a Labsystems Multiskan ${ }^{\circledR}$ Multisoft apparatus. Percent net growth was calculated using the seven absorbance measurements (time zero, (Tz), growth control, (C), plus the test growth at the different drug concentration levels (Ti)) as follows: $((\mathrm{Ti}-\mathrm{Tz}) /(\mathrm{C}-\mathrm{Tz})) \times 100$ for concentrations for which $\mathrm{Ti}>/=\mathrm{Tz}$ and $((\mathrm{Ti}-\mathrm{Tz}) / \mathrm{Tz}) \times 100$ for concentrations for which $\mathrm{Ti}<\mathrm{Tz}$. The results are expressed as the mean of three independent experiments \pm s.e.m.

\section{Evaluation of xanafide antitumour activity using the in vivo hollow fibre assay}

The in vivo hollow fibre test was performed using the original NCI protocol (Hollingshead et al, 1995). Confluent monolayers of MCF-7 and MDA-MB-231 cells were harvested, collected by centrifugation and resuspended in conditioned medium. In preliminary NCI studies, cell growth was assessed with fibres containing various cell densities. As a result, cell densities of $2.5 \times 10^{6}$ and $5 \times 10^{6}$ cells $\mathrm{ml}^{-1}$ were found to be suitable for drug studies with MCF-7 and MDA-MB-231 cell lines, respectively. Fibres filled with cells at the respective densities were incubated in 6-well plates overnight at $37^{\circ} \mathrm{C}$ in a $5 \% \mathrm{CO}_{2}$ atmosphere. Female athymic $\mathrm{NCr} n u / n u$ mice at 5-6 weeks of age were obtained from Taconic. Each mouse hosted up to six fibres, which were cultured in two physiological compartments. For intraperitoneal (i.p.) implants, a small incision was made through the skin and musculature of the dorsal abdominal wall, the fibre samples were inserted into the peritoneal cavity in a craniocaudal direction and the incision was closed with skin staples. For subcutaneous (s.c.) implants, a small skin incision was made at the nape of the neck to allow insertion of an 11-gauge tumour implant trocar. The trocar, containing the hollow fibre samples, was inserted caudally through the s.c. tissues and fibres were deposited during withdrawal of the trocar. The incision was closed with a skin staple. 
Mice were randomised into three groups: saline control group $(n=6)$, xanafide and docetaxel treated groups $(n=3$ for each group). Xanafide was dosed at the maximum tolerated dose $30 \mathrm{mg} \mathrm{kg}^{-1}$, on the basis of reported in vivo studies with amonafide (Dorr et al, 2001), and docetaxel at 5 and $12.5 \mathrm{mg} \mathrm{kg}^{-1}$ based on previous paclitaxel NCI tested doses (Hollingshead M, unpublished data). Both agents, in PBS were given once daily by i.p. injection from day 3-7 after implantation as reported previously (Hollingshead et al, 1995). Animals were monitored daily and clinical signs and body weights were recorded daily.

On day 8, mice were killed and fibres were retrieved. The fibres were placed into 6-well plates, with each well containing $2 \mathrm{ml}$ of fresh, prewarmed culture medium and allowed to equilibrate for $30 \mathrm{~min}$ at $37^{\circ} \mathrm{C}$. To define the viable cell mass contained within the intact hollow fibres, a 3-(4,5-dimethylthiazol-2-yl)-2,5-diphenyltetrazolium bromide (MTT) dye conversion assay was used. Briefly, $1 \mathrm{ml}$ of prewarmed culture medium containing $1 \mathrm{mg} \mathrm{MTT} \mathrm{ml}^{-1}$ was added to each dish. After incubating at $37^{\circ} \mathrm{C}$ for $4 \mathrm{~h}$, the culture medium was aspirated and the samples were washed twice with normal saline containing $2.5 \%$ protamine sulphate solution followed by overnight incubation at $4{ }^{\circ} \mathrm{C}$. To assess the optical density of the samples, the fibres were transferred to 24-well plates, cut in half and allowed to dry overnight. The formazan was extracted from each sample with dimethylsulphoxide $\left(250 \mu \mathrm{l}\right.$ well $\left.^{-1}\right)$ for $4 \mathrm{~h}$ at room temperature on a rotation platform. Aliquots $(150 \mu \mathrm{l})$ of extracted MTT formazan were transferred to individual wells of 96-well plates and assessed for optical density at a wavelength of $540 \mathrm{~nm}$. Results are expressed as \% growth inhibition compared to control \pm s.d.

\section{Statistical analysis}

The comparisons between the untreated and treated groups were analyzed using the Student's $t$-test. Two-sided $P$-values less than 0.05 were considered statistically significant.

\section{RESULTS}

\section{In vitro antiproliferative activity of xanafide in human breast cancer cells}

A panel of four human breast cancer cell lines: MCF-7, MDA-MB231, SKBR-3 and T47D was used in this study. Their molecular characteristics are listed in Table 1. Using the SRB assay, the cytotoxicity profile of xanafide was compared with those of five anticancer drugs widely used in the clinic: paclitaxel, docetaxel, doxorubicin, gemcitabine and vinorelbine. The results were expressed as GI50 and TGI values and summarised in Table 2.

After $48 \mathrm{~h}$ exposure time, xanafide demonstrated a steep response curve in the four breast cell lines tested (Figure 1A-D). Xanafide inhibited the growth of the ER-positive MCF-7 and T47D cells in a concentration-dependent manner, with an average $\mathrm{GI}_{50}$ value of 5 and $20 \mu \mathrm{M}$, respectively. Xanafide also inhibited the growth of the ER-negative SKBR-3 and MDA-MB-231 cells in a concentration-dependent manner, with an average $\mathrm{GI}_{50}$ value of 6 and $10 \mu \mathrm{M}$, respectively (Table 2). T47 D was the less sensitive to the antiproliferative effect of xanafide (Figure 1D). Notably, no total growth inhibition of T47D was obtained which could, in part, be due to the long doubling time of this cell line $(45.5 \mathrm{~h})$.

To better visualise the differences in the cytotoxicity to achieve complete cell growth inhibition for all the agents, TGI concentrations (resulting in total growth inhibition) were expressed. At doses higher than the TGIs, net cell killing was observed in the four breast cell lines tested: MCF-7, MDA-MB-231, SKBR-3 and T47D (Table 2).

In MCF-7 cell line, xanafide exhibited a 1.7-2.2-fold lower TGI concentration than those of docetaxel and paclitaxel, respectively. Vinorelbine and doxorubicin induced similar effects and their TGI concentrations were 10 -fold higher than that of xanafide. No total growth inhibition was achieved with gemcitabine (Table 2).

In MDA-MB-231 cell line, doxorubicin induced total growth inhibition at the lowest concentrations: $15 \mu \mathrm{M}$, whereas paclitaxel, docetaxel and xanafide exhibited comparable TGI values: 20, 25 and $35 \mu \mathrm{M}$. Vinorelbine and gemcitabine were less potent as shown by their respective 2.6- to 5.7-fold higher TGI concentrations, respectively (Table 2 ).

In SKBR-3 cells, gemcitabine and docetaxel induced total growth inhibition at $30 \mu \mathrm{m}$. Paclitaxel, xanafide and vinorelbine exhibited comparable TGI concentrations, 35,45 and $50 \mu \mathrm{M}$, respectively. The TGI for doxorubicin was $80 \mu \mathrm{M}$, 9-fold higher than that of xanafide (Table 2).

In T47D cell line, vinorelbine and gemcitabine induced similar cytotoxicity (TGI concentration of $17 \mu \mathrm{M}$ ). Paclitaxel and docetaxel showed TGI concentrations of 35 and $60 \mu \mathrm{M}$, respectively. Xanafide did not induce any complete growth inhibition in this cell line (Table 2).

These results indicate that the four breast cell lines tested exhibited differential sensitivity to xanafide and the common chemotherapeutic agents tested. Considering the TGI concentrations (Table 2) and the net cell killing achieved by xanafide, MCF-7 was the most sensitive cell line; MDA-MB-231 and SKBR-3 were almost equally sensitive while T47D was less responsive to this agent.

\section{In vivo antitumour activity}

On the basis of its cytotoxic activity in vitro, xanafide was further evaluated for in vivo activity in two ER + and ER- breast cancer cell lines, MCF-7 and MDA-MB-231, respectively. The two cell lines were implanted i.p. and s.c. in $\mathrm{NCr}$ nude mice using the hollow fibre assay. Animals were treated with saline (control group), docetaxel dosed at 5 and $12.5 \mathrm{mg} \mathrm{kg}^{-1}$, i.p., or xanafide at $30 \mathrm{mg} \mathrm{kg}^{-1}$, i.p. on a q.d. $\times 5$ treatment schedule, beginning on day 2 post-fibre implantation (days $3-7$ ).

As shown in Figure 2, in the fibres retrieved from the i.p. sites, xanafide, administered as single agent, was effective at reducing the tumour cells growth of MCF-7 and MDA-MB-231 by 41 and

Table I Characteristics of breast cell lines

Topo-II levels (absorbance)

\begin{tabular}{|c|c|c|c|c|c|}
\hline & & & & & \\
\hline Cell line & ER status & p53 status & Her levels & $\alpha$ & $\beta$ \\
\hline MDA-MB-23I & - & $m u$ & Low & 724 & 304 \\
\hline
\end{tabular}

Abbreviation: $E R=$ oestrogen receptor. ${ }^{\text {a }}$ Houlbrook et al (1995). 
Table 2 In vitro profile of xanafide in comparison with common drugs

GI50/TGI \pm s.e.m. $(\mu \mathrm{M})$

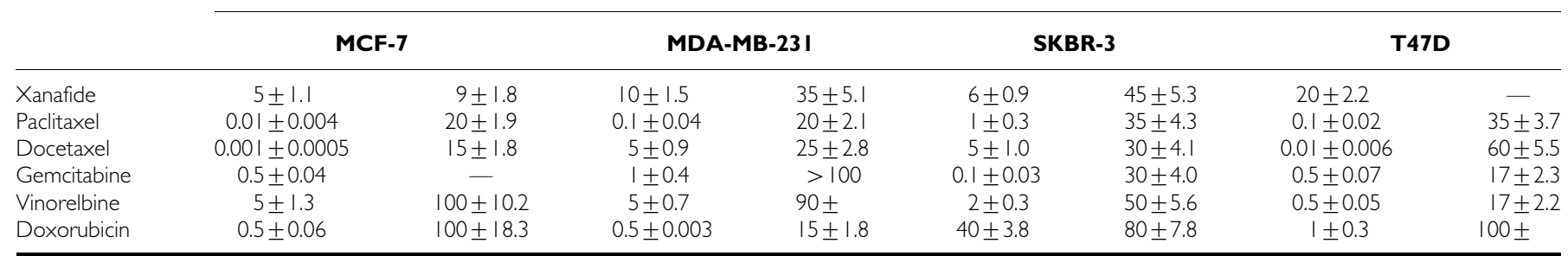

GI50 and TGI concentrations calculated after $48 \mathrm{~h}$ exposure. Results are mean of three independent experiments. GI50 was calculated as the drug concentration that reduced the number of cells to $50 \%$ of the number of cells before drug addition. TGl is the drug concentration that achieved total growth inhibition of the cells.
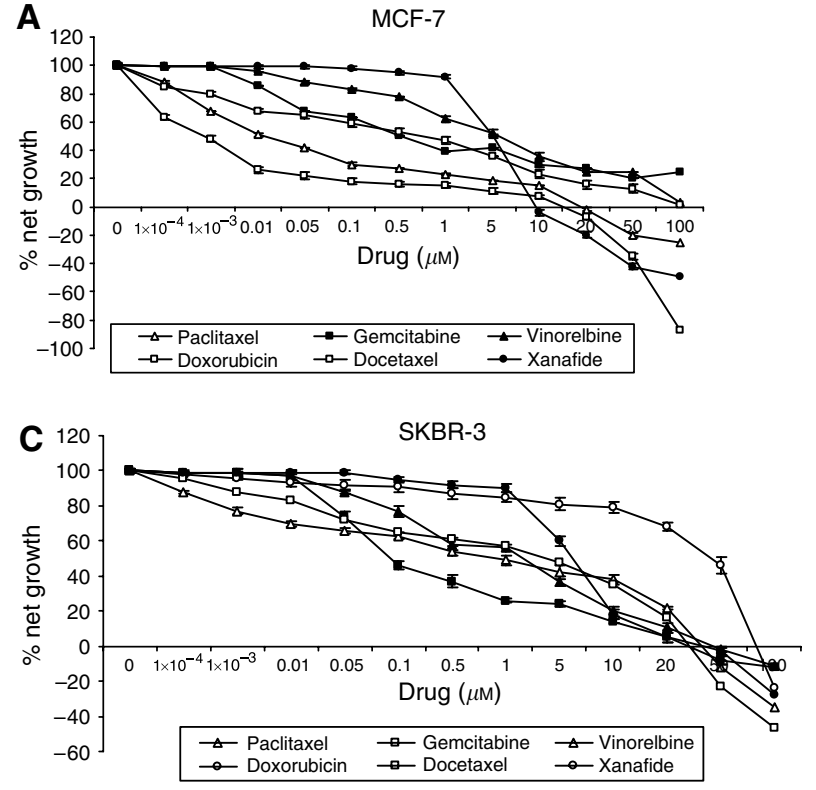
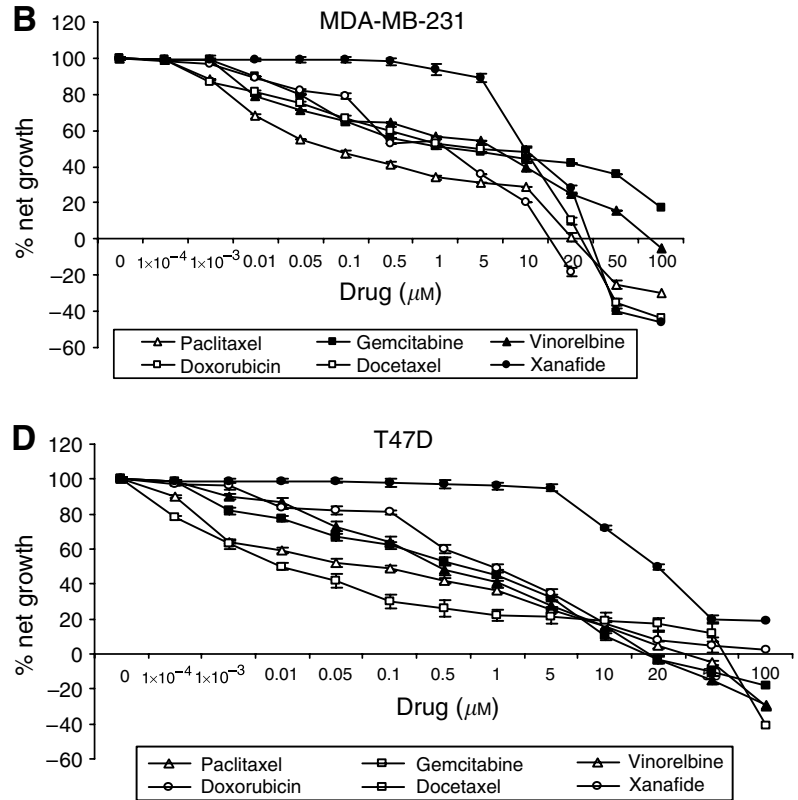

Figure I In vitro cytotoxicity of xanafide in breast cell lines in comparison with common drugs. (A) MCF-7, (B) MDA-MB-23I, (C) SKBR-3, (D) T47D. Xanafide ( $)$, vinorelbine $(\boldsymbol{\Lambda})$, gemcitabine $(\boldsymbol{\square})$, doxorubicin $(\bigcirc)$, paclitaxel $(\triangle)$ and docetaxel $(\square)$. Cells were exposed to the different drugs for $48 \mathrm{~h}$. \% Net growth was determined with the SRB assay as described in Materials and Methods. The results are the average of three separate experiments \pm s.e.m.

$46 \%$, respectively, as compared with control $(P<0.05)$. Docetaxel exhibited dose-dependent growth inhibitory effects. At the lowest dose used, $5 \mathrm{mg} \mathrm{kg}^{-1}$, docetaxel produced a growth inhibition of 36 and $45 \%$, in MCF-7 and MDA-MB-231, respectively $(P<0.05)$. At $12.5 \mathrm{mg} \mathrm{kg}^{-1}$, the growth inhibition elicited was 39 and $51 \%$, in MCF-7 and MDA-MB-231, respectively $(P<0.05)$. These results show that xanafide was slightly more potent than docetaxel at its highest dose, in MCF-7. In contrast, its potency was lower than that of docetaxel in MDA-MB-231.

In the fibres retrieved from the s.c. sites (Figure 2), xanafide administered as single agent produced comparable growth inhibition in MCF-7 and MDA-MB-231 cell lines, reducing the growth by 42 and $40 \%$, respectively $(P<0.05)$. Docetaxel showed dose-dependent inhibitory effects. At the lowest dose, the growth inhibition obtained was 31 and 36\%, in MDA-MB-231 and MCF-7, respectively $(P<0.05)$. At the highest dose used, $12.5 \mathrm{mg} \mathrm{kg}^{-1}$, the growth inhibition induced was 42 and $46 \%$, in MCF-7 and MDA-MB-231, respectively $(P<0.05)$.

Body weights were recorded daily during the course of the study, and expressed as the difference observed relative to start of treatment. For the docetaxel treated mice no loss in body weight was observed while in the xanafide treated mice, body weight was reduced by $12 \%$ by day 8 , which was within the acceptable range based on NCI established criteria (Figure 3).

\section{DISCUSSION}

Amonafide, a DNA-intercalating agent and topoisomerase II inhibitor, has been used as first-line treatment for MBC. However, amonafide is extensively metabolised, including $\mathrm{N}$-acetylation to an active metabolite, $\mathrm{N}$-acetyl amonafide, and the extent of amonafide $\mathrm{N}$-acetylation is the major determinant of myelosuppression (Ratain et al, 1995). As a result, several compounds having structural analogy to amonafide have been synthesized (Sami et al, 1993, 2000; Dorr et al, 2001). Among these, azonafide has shown high potency against a panel of human colon cancer cell lines and was active against i.p. P388 leukaemia and s.c. B16 melanoma murine models (Sami et al, 1993).

Xanafide, the new formulation of amonafide, has been synthesized aiming at reducing the toxicity and improving the therapeutic index of the parent drug, amonafide. We have previously shown that xanafide and amonafide hydrochloride have comparable and significant inhibitory activity both in vitro against the three cell lines of the NCI prescreen program: H460 (non-small cell lung), SF268 (glioma) and MCF-7 (breast), and in vivo in MCF-7 (breast), COLO205 (colon) and PC-3 (prostate) cell lines, using the hollow fibre assay (Alami et al, 2003).

The aim of this study was to further investigate the antitumour effects of xanafide, in comparison with common breast drugs in a 


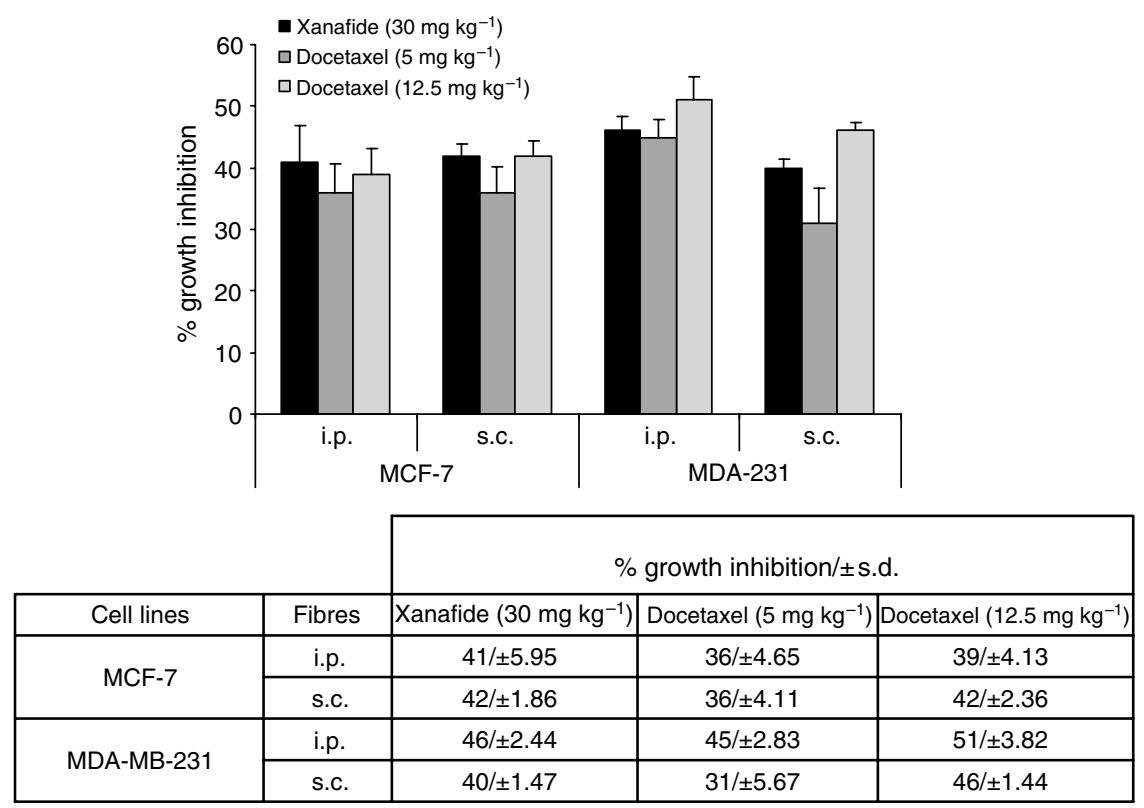

Figure 2 Antitumour effect of xanafide in comparison with docetaxel in MCF-7 and MDA-MB-23I breast cell lines in the in vivo hollow fibre assay. Fibres filled with the cells were implanted at the intraperitoneal (i.p.) and subcutaneous (s.c.) compartments of NCr nu/nu mice. The animals were treated with saline (control), xanafide $\left(30 \mathrm{mg} \mathrm{kg}{ }^{-1}\right.$ ) or docetaxel $\left(5 \& 12.5 \mathrm{mg} \mathrm{kg}^{-1}\right)$. Drugs were administrated once daily by i.p. injection from days $3-7$ after implantation. On day 8, mice were killed and fibres were retrieved. The effectiveness of the drugs was evaluated on the basis of growth inhibition of the cells determined by MTT assay, as described in Materials and Methods.

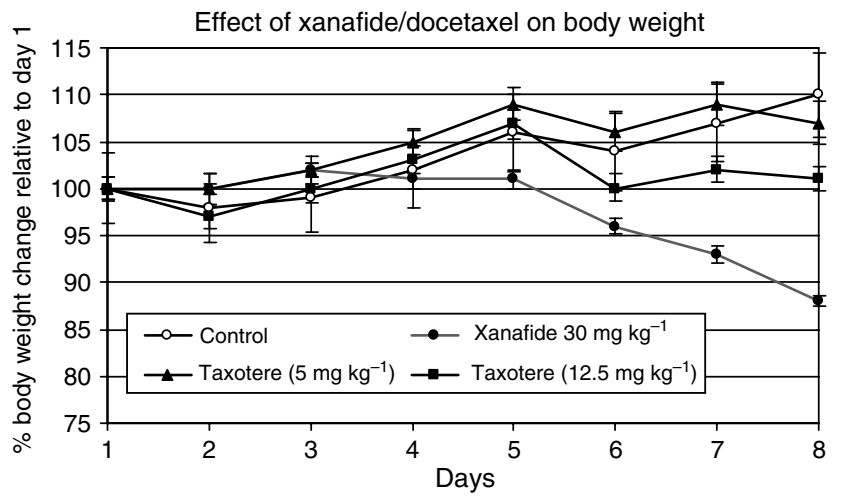

Figure 3 Relative body weight change. Mice were implanted with i.p. and s.c. fibres filled with MCF-7 and MDA-MB-23I breast cell lines. Mice were treated with vehicle $(-\mathrm{O}-)$, xanafide (- - - ), docetaxel $\left(5 \mathrm{mg} \mathrm{kg}^{-1}\right)(-\boldsymbol{\Delta}-)$ and docetaxel $\left(12.5 \mathrm{mg} \mathrm{kg}^{-1}\right)(-\mathbf{-}-)$.

panel of breast cell lines well characterised for their oestrogen receptor, p53 status, Her-2 and topoisomerase II $\alpha$ and $\beta$ levels: MCF-7, MDA-MB-231, SKBR-3 and T47D (Table 1). Xanafide exhibited a steep response curve in all four cell lines tested (Figure 1A-D). The GI 50 and TGI concentrations clearly show that these cell lines displayed differential sensitivity to xanafide with MCF-7 (ER ${ }^{+} / \mathrm{p} 53$ wild-type) being the most sensitive and T47 $\mathrm{D}(\mathrm{ER}+/ \mathrm{p} 53$ mutated) the most resistant. Although this cell line was responsive to low doses of the other drugs tested, the lack of activity of xanafide in the T47D could be, in part, due to its long doubling time.

Furthermore, xanafide has proved to be more active than the taxanes, gemcitabine, vinorelbine and doxorubicin in MCF-7. The Two ER ${ }^{-} / \mathrm{p} 53$ mutated cell lines (MDA-MB-231 and SKBR-3) displayed comparable in vitro responsiveness to xanafide as demonstrated by their respective GI50 and TGI concentrations (Table 2).
Our in vitro results correlate with the in vivo data where xanafide was slightly more potent than docetaxel at its highest dose, in MCF-7 (Figure 2). These findings suggest a specificity of xanafide against the $\mathrm{ER}^{+}$, p53 w/t MCF-7 cell line.

These data raise the question of what are the mechanisms underlying the response to xanafide. Several clinical observations indicate a role for oestrogen and ER in the development, progression and treatment of human breast cancer (Angeloni et al, 2004). In addition, there is substantial evidence showing that alterations in the tumour suppressor gene, p53, are associated with the development of several types of cancer, including breast cancer (Hollstein et al, 1991). Considering that the p53 gene is mutated in approximately $50 \%$ of all tumours, its role in the control of cell cycle progression, maintenance of DNA integrity and induction of apoptosis is well documented (Zhan et al, 1993; Yonish-Rouach et al, 1995). It has also been shown that in breast cancer, p53 mutations are associated with a decrease in disease-free and overall survival of patients (Sirvent et al, 2001). Previous studies have reported that the ability of p53 to control the expression of $\mathrm{ER} \alpha$ could suggest that specific p53 mutations in breast tumours may contribute not only to oncogenesis and drug resistance, but also to the more aggressive phenotype associated with the loss of ER expression. Interestingly, a high percentage of breast tumours with p53 mutations are ER-negative (Berns et al, 1996).

Our results showed that the two $\mathrm{ER}^{-} / \mathrm{p} 53$ mutated cell lines MDA-MB-231 and SKBR-3 exhibited moderate sensitivity to xanafide, whereas T47 D (ER $+/ \mathrm{p} 53$ mutated) was more resistant to xanafide, with no induced cell killing, as compared with the extent of the anti-proliferative effect observed with MCF-7 $(\mathrm{ER}+/ \mathrm{p} 53 \mathrm{wt})($ Table 2$)$. These findings may partially support a mechanism of responsiveness to xanafide in ER + breast cancer where an active p53 gene is required. Additionally, related studies have shown that $\mathrm{p} 53$ was a negative regulator of the ER signalling pathways, suggesting a crosstalk between p53 and ER in breast cancer ( $\mathrm{Yu}$ et al, 1997).

On the other hand, the DNA damage induced by topo II inhibitors triggers the p53-dependent apoptotic pathway that lead 
to cell cycle arrest (p21, cyclins, GADD45, PCNA) or to apotosis (Bcl-2, Bax, surviving, scotin) (Valkov and Sullivan, 2003). Related studies using tumour cell lines tested for their p53 status have shown that mutations of p53 correlate with drug resistance to a wide spectrum of anticancer agents, including topo II inhibitors (O'Connor et al, 1997; Sirvent et al, 2001). Usually, wild-type p53 expression predisposes cells to a more rapid rate of cell death after DNA damage. Previous studies have reported that non-small cell lung cancer cells having p53 mutations showed significantly poorer response to intensive chemotherapy that included etoposide and epirubicin (Vogt et al, 2002). In addition, treatment of MCF-7 with doxorubicin resulted in an increase of p53 expression, confirming a p53-mediated response to doxorubicin in cells containing a wildtype p53 gene product (Liem et al, 2003). Additional work has revealed that loss of wild-type p53 function confers resistance to etoposide in neuroblastoma cells (Keshelava et al, 2001) and in glioma cells (Yin et al, 2000). Others have also reported that p53 status in breast cancer patients correlated with a poor response to epirubicin (Mottolese et al, 2000). Furthermore, it has been postulated that the cell cycle arrest effect of wild-type p53 on cell cycle regulated topo II $\alpha$ expression could potentially provide a sufficient amount of target enzyme for optimisation of treatment with topoisomerase II inhibitors (Valkov and Sullivan, 2003), thus supporting the greater potency of xanafide in MCF-7 cell line.

\section{REFERENCES}

Alami N, Paterson J, Banerjee K, Yu Q, Grieshaber C, Leyland-Jones B (2003) Cytotoxicity of Two New Derivatives of Amonafide in Human Tumor Cell lines In vitro and In vivo Using the Hollow Fiber Assay. Washington, DC: 94th Annual AACR Meeting

Andersson BS, Beran M, Bakic M, Silberman LE, Newman RA, Zwelling LA (1987) In vitro toxicity and DNA cleaving capacity of benzisoquinolinedione (nafidimide; NSC 308847) in human leukemia. Cancer Res 47: 1040 - 1044

Angeloni SV, Martin MB, Garcia-Morales P, Castro-galache MD, Ferragut JA, Saceda M (2004) Regulation of estrogen receptor-alpha expression by the tumor suppressor gene p53 in MCF-7 cells. J Endocrinol 180: 497-504

Berns EM, Klijn JG, Smid M, van Staveren IL, Look MP, van Putten WL, Foekens JA (1996) TP53 and MYC gene alterations independently predict poor prognosis in breast cancer patients. Gene Chromosome Canc 16: $170-179$

Blum JL, Jones SE, Buzdar AU, LoRusso PM, Kuter I, Vogel C, Osterwalder B, Burger HU, Brown CS, Griffin T (1999) Multicenter phase II study of capecitabine in paclitaxel-refractory metastatic breast cancer. J Clin Oncol 17: 485

Brana MF, Ramos A (2001) Naphthalimides as anti-cancer agents: synthesis and biological activity. Curr Med Chem Anti-Cancer Agents 1: 237-255

Costanza ME, Berry D, Henderson IC, Ratain MJ, Wu K, Shapiro C, Duggan D, Kalra J, Berkowitz I, Lyss AP (1995) Amonafide: an active agent in the treatment of previously untreated advanced breast cancer-a cancer and leukemia group B study (CALGB 8642). Clin cancer Res 1: 699-704

Dorr RT, Liddil JD, Sami SM, Remers W, Hersh EM, Alberts DS (2001) Preclinical antitumor activity of the azonafide series of anthracene-based DNA intercalators. Anticancer Drug 12: 213-220

Epstein RJ, Smith PJ (1988) Estrogen-induced potentiation of DNA damage and cytotoxicity in human breast cancer cells treated with topoisomerase II-interactive antitumor drugs. Cancer Res 48: 297-303

Esteva FJ, Valero V, Pusztai L, Boehnke-Michaud L, Budzar AU, Hortobagyi GN (2001) Chemotherapy of metastatic breast cancer: what to expect in 2001 and beyond. Oncologist 6: $133-146$

Ghersi D, Wilcken N, Simes J, Donoghue E (2005) Taxane containing regimens for metastatic breast cancer. Cochrane Database Syst Rev 18: CD003366

Gralow JR (2005) Optimizing the treatment of metastatic breast cancer. Breast Cancer Res Treat 89: S9-S15

Hollingshead MG, Alley MC, Camalier RF, Abbott BJ, Mayo JG, Malspeis L, Grever MR (1995) In vivo cultivation of tumor cells in hollow fibers. Life Sci 57: $131-141$
In addition, the topoisomerase II $\alpha$ gene, TOP $2 \alpha$, is located at chromosome band 17q12-q21, close to the ErbB-2 oncogene (HER$2 /$ neu), which is the most commonly amplified oncogene in breast cancer. Because of the physical proximity to ErbB-2, copy number aberrations may also occur in the topoII $\alpha$ gene, which may be related to the altered chemosensitivity to topoII inhibitors (Jarvinen and Liu, 2006). Our results show that xanafide sensitivity was not correlated with expression levels of both topoisomerase II $\alpha$ and $\beta$. Considering the TGI concentrations, MDA-MB-231 and SKBR-3 expressing low levels and high levels of both isoforms, respectively, exhibited comparable sensitivity to xanafide. Our data are in agreement with those reported by Tewey et al (1984) where sensitivity to the topo II inhibitor, doxorubicin, showed no correlation with expression of either of the topoisomerase II isoforms.

In view of the previous findings together with our results, we speculate that p53 and ER and their signalling pathways are likely important determinants of breast tumour cells sensitivity to xanafide. Understanding these relationships may lead to strategies for xanafidebased chemotherapy optimisation and further precision targeting of tumour cells to avoid drug resistance and thereby chemotherapy failure. Furthermore, the steep response curves of xanafide activity in the four breast cell lines tested suggest that accurate individualised patient dosing is critically important for maximising clinical response while minimising neutropenic variability.

Hollstein M, Sidransky D, Vogelstein B, Harris CC (1991) p53 mutations in human cancers. Science 253: 49-53

Hortobagyi GN, Piccart-Gebhart MJ (1996) Current management of advanced breast cancer. Semin Oncol 23: 1-5

Houlbrook S, Addison CM, Davies SL, Carmichael J, Stratford IJ, Harris AL, Hickson ID (1995) Relationship between expression of topoisomerase II isoforms and intrinsic sensitivity to topoisomerase II inhibitors in breast cancer cell lines. Br J Cancer 72: 1454-1461

Hsiang YH, Jiang JB, Liu LF (1989) Topoisomerase II-mediated DNA cleavage by amonafide and its structural analogs. Mol Pharmacol 36: $371-376$

Jarvinen TA, Liu ET (2006) Simultaneous amplification of HER-2 (ERBB2) and topoisomerase IIalpha (TOP2A) genes - molecular basis for combination chemotherapy in cancer. Curr Cancer Drug Targets 6: $579-602$

Keshelava N, Zuo JJ, Chen P, Waidyaratne SN, Luna MC, Gomer CJ, Triche TJ, Reynolds CP (2001) Loss of p53 function confers high-level multidrug resistance in neuroblastoma cell lines. Cancer Res 61: 6185-6193

Kroger N, Achterrath W, Hegewisch-Becker S, Mross K, Zander AR (1999) Current options in treatment of anthracycline-resistant breast cancer. Cancer Treat Rev 25: 279-291

Liem AA, Appleyard MV, O'Neill MA, Hupp TR, Chamberlain MP, Thompson AM (2003) Doxorubicin and vinorelbine act independently via p53 expression and p38 activation respectively in breast cancer cell lines. Br J Cancer 88: $1281-1284$

Livingston RB, Ellis GK, Gralow JR, Williams MA, White R, McGuirt C, Adamkiewicz BB, Long CA (1997) Dose-intensive vinorelbine with concurrent granulocyte colony-stimulating factor support in paclitaxelrefractory metastatic breast cancer. J Clin Oncol 15: 1395-1400

Martin M, Ruiz A, Munoz M, Balil A, Garcia-Mata J, Calvo L, Carrasco E, Mahillo E, casado A, Garcia-Saenz JA, Escudero MJ, Guillem V, Jara C, Ribelles N, Salas F, Soto C, Morales-Vasquez F, Rodriguez CA, Adrover E, Mel JR (2007) Gemcitabine plus vinorelbine versus vinorelbine monotherapy in patients with metastatic breast cancer previously treated with anthracyclines and taxanes: final results of the phase III Spanish Breast Cancer Research Group (GEICAM) trial. Lancet Oncol 8: 219-225

Montero A, Fossella F, Hortobagyi G, Valero V (2005) Docetaxel for treatment of solid tumours: a systematic review of clinical data. Lancet Oncol 6: 229-239

Mottolese M, Benevelo M, Del Monte G, Buglioni S, Papaldo P, Nistico C, Di Filippo F, Vasselli S, Vici P, Botti C (2000) Role of p53 and BCL-2 in high-risk breast cancer patients treated with adjuvant anthracyclinebased chemotherapy. J Cancer Res Clin Oncol 126: 722-729 
O'Connor PM, Jackman J, Bae I, Myers TG, Fan S, Mutoh M, Scudiero DA, Monks A, Sausville EA, Weinstein JN, Friend S, Fornace AJ, Kohn KW (1997) Characterization of the p53 tumor suppressor pathway in cell lines of the National Cancer Institute anticancer drug screen and correlations with the growth-inhibitory potency of 123 anticancer agents. Cancer Res 57: 4285-4300

Pronzato P, Rondini M (2006) First line chemotherapy of metastatic breast cancer. Ann Oncol 17: v165-v168

Ratain MJ, Mick R, Berezin F, Janisch L, Schilsky RL, Vogelzang NJ, Lane LB (1993) Phase I study of amonafide dosing based on acetylator phenotype. Cancer Res 53: 2304-2308

Ratain MJ, Mick R, Berezin F, Janisch L, Schilsky RL, Williams SF, Smiddy J (1991) Paradoxical relationship between acetylator phenotype and amonafide toxicity. Clin Pharmacol Ther 50: 573-579

Ratain MJ, rosner G, Allen SL, Costanza M, Van Echo DA, henderson IC, Schilsky RL (1995) Population pharmacodynamic study of amonafide: a Cancer and Leukemia Group B study. J Clin Oncol 13: 741-747

Sami SM, Dorr RT, Alberts DS, Remers WA (1993) 2-substituted 1, 2dihydro-3H-dibenz[de, h]isoquinoline-1, 3-diones. A new class of antitumor agent. $J$ Med Chem 36: 765-770

Sami SM, Dorr RT, Alberts DS, Sólyom AM, Remers WA (2000) Analogues of amonafide and azonafide with novel ring systems. J Med Chem 43: $3067-3073$

Schiff PB, Fant J, Horwitz SB (1979) Promotion of microtubule assembly in vitro by Paclitaxel. Nature 277: 665-667

Sirvent JJ, Fortuno-Mar A, Olona M, Orti A (2001) Prognostic value of p53 protein expression and clinicopathological factors in infiltrating ductal carcinoma of the breast. A study of 192 patients. Histol Histopathol 16: $99-106$
Skehan P, Storeng R, Scudiero D, Monks A, McMahon J, Vistica D, Warren JT, Bokesch H, Kenney S, Boyd MR (1990) New colorimetric cytotoxicity assay for anticancer-drug screening. J Natl Cancer Inst 82: 1107-1112

Tewey KM, Rowe TC, Yang L, Halligan BD, Liu LF (1984) Adriamycininduced DNA damage mediated by mammalian DNA topoisomerase II. Science 226: $466-468$

Valerio MR, Cicero G, Armata MG, Bajardi E, Crosta A, Badalamenti G, Arcara C, Agosta G, Vieni S, Latteri F, Russo A, Gulotta G, Gebbia N (2001) Gemcitabine (G) in Pre-treated Breast Cancer (BC). San Francisco, CA: 37th Annual Meeting of the American Society of Clinical Oncology, 20, 51b, abstract \# 1953

Valkov NI, Sullivan DM (2003) Tumor p53 status and response to topoisomerase II inhibitors. Drug Resist Updat 6: 27-39

Vogelstein B, Lane D, Levine AJ (2000) Surfing the p53 network. Nature 408: $307-310$

Vogt P, Zaczek A, Klinke F, Granetzny A, Bielawski K, Falkiewicz B (2002) p53 gene status in relation to ex vivo chemosensitivity of non-small cell lung cancer. J Cancer Res Clin Oncol 128: 141-147

Yin D, Tamaki N, Kokunai T (2000) Wild-type p53-dependent etoposideinduced apoptosis mediated by caspase- 3 activation in human glioma cells. J Neurosurg 93: 289-297

Yonish-Rouach E, Deguin V, Zaitchouk T, Breugnot C, Mishal Z, Jenkins JR, May E (1995) Transcriptional activation plays a role in the induction of apoptosis by transiently transfected wild-type p53. Oncogene 11: 2197-2205

Yu CL, Driggers P, Barrera-Hernandez G, Nunez SB, Segars JH, Cheng SY (1997) The Tumor Suppressor p53 is a negative regulator of estrogen receptor signaling pathways. Biochem Biophys Res Commun 239: 617-620

Zhan Q, carrier F, Fornace AJ (1993) Induction of cellular p53 activity by DNA-damaging agents and growth arrest. Mol Cell Biol 13: 4242-4250 